Article

\title{
The Public Value of Urban Vacant Land: Social Responses and Ecological Value
}

\author{
Gunwoo Kim \\ Landscape Architecture Program, Arizona State University, PO Box 871605, Tempe, AZ 85287-1605, USA; \\ Gunwoo.Kim.1@asu.edu; Tel.: +1-540-524-8301 \\ Academic Editors: William D. Shuster, Audrey L. Mayer and Ahjond S. Garmestani \\ Received: 29 March 2016; Accepted: 10 May 2016; Published: 17 May 2016
}

\begin{abstract}
This study reviews scholarly papers and case studies on urban vacant land to gain a stronger understanding of its public value in terms of the ecological and social benefits it can bring. This literature review offers a conceptual overview of the potential benefits of vacant land with the goal of addressing gaps in knowledge about vacant land and to provide suggestions to planners and designers on how vacant properties can be integrated with other green infrastructure in cities. There are many opportunities to redevelop vacant land to enhance its ecological and social value, and many design professionals and scholars are becoming interested in finding new ways to exploit this potential, especially with regard to planning and design. A better appreciation of the public value of urban vacant land is vital for any effort to identify alternative strategies to optimize the way these spaces are utilized for both short-term and long-term uses to support urban regeneration and renewal. This study will help planners and designers to understand and plan for urban vacant land, leading to better utilization of these spaces and opening up alternative creative approaches to envisioning space and landscape design in our urban environments.
\end{abstract}

Keywords: vacant land; green infrastructure; ecological and social value

\section{Introduction}

A variety of urban processes, including decentralization due to demographic changes, urban sprawl, de-industrialization, and people's preferences for new types of residential choices have thus led to increased vacancy rates in urban areas [1]. Overall, declining city populations and urban sprawl are the two most important reasons for the decentralization of our cities. As people moved to the suburbs, the infrastructure provided and utilization of land decreased, leaving the urban core with remnants. Depopulation of the urban core increases vacancies in urban areas. These vacancies, also known as urban voids, then become left-over, negative spaces in the urban fabric.

The term "vacant land" frequently carries a negative connation-abandoned, empty, dangerous-thus symbolizing disinvestment, blight, and decay [2,3]. As a result, it is often automatically viewed as a problem in urban areas [1]. However, vacant land may instead be viewed as valuable urban landscape that provides community benefits and/or opportunities for transformation via community redevelopment, as well as being a potential source of ecosystem services that support the health and well-being of local people [4,5]. Re-imagining urban vacant land is critical to our disciplinary and professional commitment to traditional urban land use and we need to be more open to alternative ways to "reuse wasted land" in urban areas. Vacant land can be a valuable ecological resource, acting as green infrastructure that can be used to enhance ecosystem health and promote a better quality of life for city residents [6].

Urban vacant land is not normally thought of as green infrastructure, partly because the potential community benefits provided by these spaces are not widely recognized. Vacant land suffers from both political and economic problems [7]. Most urban vacant land in the U.S. is viewed only in terms 
of its current highest and best use from an economic perspective. If it is not developable it is ignored. However, vacant land does contribute ecological and social benefits and could potentially contribute more if managed appropriately [6,8]. One way of addressing this failure is to conduct a comprehensive literature review and case studies of vacant land reuse/revitalization from Europe and North America to better understand the potential ecological benefits and opportunities provided for local communities and, thus, synthesize the findings across the examples to improve our understanding of the role of vacant land in creating healthy, livable and sustainable cities.

Urban vacant land covers a significant amount of the urban landscape in many cities. According to a 2000 Brookings Institution study, vacant land comprised an average of $15 \%$ of the land area in seventy U.S. cities [9]. The experience of many in the U.S. suggests that this vacant land represents a substantial proportion of the urban landscape that is available for strategic reuse as part of municipalities' urban development policies [10]. To avoid this blight having an adverse impact on the surrounding community, vacant land could instead be used to provide long-term or interim beneficial services such as community gardens, wildlife gardens, public plantings, and recreational areas [11].

If vacant land is managed appropriately, it can contribute both ecological and social benefits $[6,8]$. A review of the literature on the potential value of vacant land, focusing in particular on its potential ecological and social benefits, was therefore conducted in this study. The main objective was to develop a better understanding of the potential value of vacant land in terms of its ecological and social benefits in order to help determine how effectively urban vacant land can function as part of a city's green infrastructure, eventually leading to better utilization of the vacant land in our cities. The findings clearly demonstrate that urban vacant land is a vital resource and a useful component of the city's green infrastructure that can offer significant benefits and should therefore be managed to increase its effectiveness and minimize any negative effects. Vacant land may also offer new opportunities for the creative use of open spaces and alternative landscape designs, especially in otherwise heavily built-up city environments.

\section{Methods}

This study utilizes a comprehensive literature review and case studies of different types of green infrastructure projects on vacant land to help develop a better understanding of the potential value of vacant land in terms of its ecological and social value. Previous research studies discuss urban vacant land as if it were all the same, largely because there is a limited systematic categorization of different types of vacant land and few comprehensive studies into how different types of vacant land can collectively contribute, to the urban landscape. Due to this dearth of knowledge regarding the potential uses of different types of urban vacant land, it is often overlooked and not fully valued as part of the urban landscape, despite its potential ecological and social values. The design, planning, and management of vacant lands has been minimal, both in the short and long term, thus neglecting a valuable resource. A literature review was conducted to determine the status of our understanding of the related phenomena and identify previous attempts to develop a typology for urban vacant land. Electronic journal databases (i.e., Science Direct, Google Scholar, and Web of Science) were first searched by journal name to identify journals on the public value of vacant land, ecological value, social value, ecosystem services, typology, and classification in vacant land. The journals included in the literature review were Urban Forestry and Urban Greening, Sustainability, Cities, Urban Ecosystems, and Landscape and Urban Planning. Using the keywords of public value of vacant land, social value, ecological value, ecosystem services, typology-relevant articles from these journals were identified. Additionally, landmark book publications where included in the literature review.

A descriptive and interpretive approach was utilized, focusing specifically on an analysis of the typology of vacant lots, such as green space, public space, open space, and community garden. The case studies reveal how leading cities across the nation incorporate different types of vacant land as integrated systems of urban green infrastructure in their long-term plans and shed new light on how the policies they implement have an impact on the barriers and challenges related to green 
infrastructure on vacant lots across Europe and North America. The classification of different categories of urban vacant land based on their physical, biological, and social characteristics will provide a useful way to assess their potential value in the urban landscape.

To this end, this paper illustrates the typology of urban vacant land to help planners, developers, and residents better utilize these areas, using the City of Roanoke, Virginia, as a case study. A comprehensive literature review, field measurements, and observations, including photographs and analysis, were utilized, along with aerial photo interpretation and ground-truthing methods, to identify and catalog vacant parcels of land. The inventory of vacant land characteristics consisted of field observations in the area of the central Roanoke River, which includes many different types of vacant land due to the large number of derelict and underused industrial properties. The researcher was equipped with maps, a field book, tape measure, and a camera to take notes and capture the characteristics of the different types of vacant land in terms of natural and cultural factors. The field-based observational data was collected during the 2013 leaf-on season (June) to facilitate the evaluation of the environmental characteristics of the vegetation.

\section{Ecological and Social Value of Vacant Land}

The review of the published literature and case studies revealed that urban vacant land has high potential as a valuable ecological resource that provides ecosystem services that could take the form of green space, public open space, and community gardens in urban areas. These are discussed in turn below.

\subsection{Ecosystem Services of Vacant Land}

Ecosystem services are defined as the benefits people obtain from ecosystems and these can be broken down into four major areas: provisioning services (e.g., food production, water supply), regulating services (e.g., climate regulation, air pollution removal), cultural services (e.g., recreation, education), and supporting services (e.g., nutrient cycling, soil building) (Figure 1) [12]. Studies have suggested that vacant land can provide many more ecosystem services than other urban land uses, such as gardens or lawns, including bio control [13], soil food web productivity [14], storm water retention services [15], habitat provision services, and climate regulation and carbon capture [16]. Vacant land vegetation can be a very cost-effective way of reducing the need for hard storm water management infrastructure and can also mitigate urban runoff by capturing a significant percentage of runoff $[8,17]$.

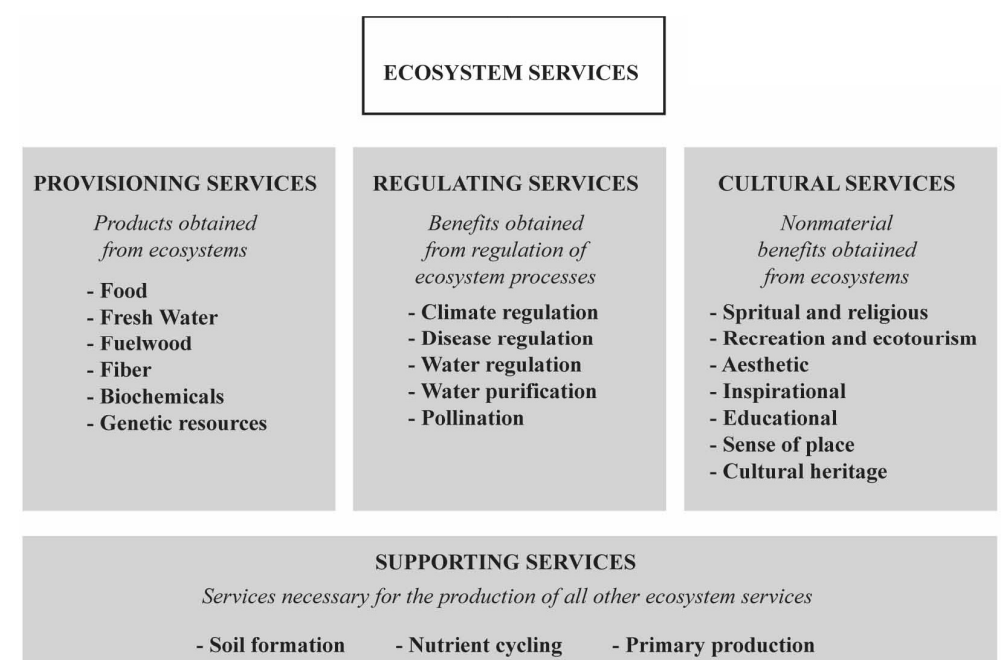

Figure 1. Categories of ecosystem services (Source: Millennium Ecosystem Assessment, 2003) [12], permission to use granted by: Island Press (16 May 2016). 
A major driver for sources providing ecosystem services are land cover by vegetation and bare soil, both of which generally provide more ecosystem services related to the provision, regulation, and support of ecosystem services than non-vegetated and impervious surfaces [1]. The most recent research reported that trees in Roanoke's vacant land store about 97,500 ton of carbon, valued at $\$ 7.6$ million. In addition, these trees remove about $2090 \mathrm{t}$ of carbon (valued at $\$ 164,000$ ), and about $83 \mathrm{t}$ of air pollutants (valued at $\$ 916,000$ ) every year, which is high relative to other land uses in Roanoke. Trees on vacant land in the city are estimated to reduce annual residential energy costs by $\$ 211,000$ for the city's 97,000 residents. The structural value of the trees growing on vacant land is estimated at $\$ 169$ million [6,8]. Trees on vacant land are growing in more natural conditions and there are more large trees per ha [8]. They are likely large on average and thus have more above-ground biomass, providing more carbon storage than for other land uses. (Table 1) [6].

Table 1. Comparison of urban forests in Roanoke by land use: per ha values of trees' structural and functional values.

\begin{tabular}{ccccccc}
\hline Land Use & $\begin{array}{c}\text { Number of } \\
\text { Trees per } \\
\text { ha (SE) }\end{array}$ & $\begin{array}{c}\text { Carbon } \\
\text { Storage } \\
\mathbf{( k g / h a )}(\mathrm{hE})\end{array}$ & $\begin{array}{c}\text { Carbon } \\
\text { Storage } \\
\text { Value (US\$) } \\
\text { per ha (SE) }\end{array}$ & $\begin{array}{c}\text { Carbon } \\
\text { Sequestration } \\
\mathbf{( k g / y e a r / h a )} \\
\mathbf{( S E )}\end{array}$ & $\begin{array}{c}\text { Carbon } \\
\text { Removal } \\
\text { Value (US\$) } \\
\text { per ha (SE) }\end{array}$ & $\begin{array}{c}\text { Structural } \\
\text { Value (US\$) } \\
\text { per ha (SE) }\end{array}$ \\
\hline Commercial & $153.3(94.9)$ & $10,585(4499)$ & $825.6(350.9)$ & $854.8(452.2)$ & $66.7(35.2)$ & $97,599(50,223)$ \\
Industrial & $79.7(28.6)$ & $7314(2422)$ & $570.5(188.9)$ & $483.8(139.5)$ & $37.7(10.8)$ & $60,822(17,580)$ \\
Residential & $280.7(41.4)$ & $36,997(4735)$ & $2885.8(369.3)$ & $2279.0(290.5)$ & $177.8(22.6)$ & $241,202(30,605)$ \\
Vacant & $63.4(7.2)$ & $29,407(4908)$ & $2293.7(382.8)$ & $630.7(86.7)$ & $49.2(6.7)$ & $50,943(7341)$ \\
\hline \multicolumn{7}{c}{ SE $=$ Standard error of total. }
\end{tabular}

Other research suggests that vacant land can provide ecological habitats for a wide range of plants, mammals, birds, and insects, thus supporting biodiversity (supporting services) and urban wildlife health [18]. Vacant land can also play a role in urban stormwater management and provide wetland plant communities that can help filter and disperse pollution (regulating services), as well as adding to a city's green network systems by providing ecological corridors $[8,17,18]$. In the UK, Camley Street Natural Park in London is an example of this kind of function. It was created from an old coal yard (brownfield) in 1984 and now serves as an innovative and internationally acclaimed wildlife reserve on the banks of the Regent's Canal. In spite of its small size (2 acres), it includes a diversity of habitats, such as woodland, wildflower meadow, marsh, reed bed, garden bed, and pond, which support an impressive list of plant and animal species [18]. Also in London, Gillespie Park contains different types of habitats, including a pond, woodland, and natural grassland, which were created by extending an existing park onto a disused railroad, providing an unusually species-rich habitat close to the center of the city [19]. Traditionally, railroad tracks provide long wildlife corridors, and the Northern Heights Parkland Walk through two London boroughs [20] includes over 200 species of wildflowers and hedgehogs, foxes, butterflies, and a vast array of birds recorded along the route [18].

Natur-Park Schöneberger Südgelände in Berlin contains a number of different types of habitats, some of which will continue to evolve over time (Figure 2) [21]. Other areas are maintained for their species richness, which can provide different opportunities for visitors to not only enjoy just the scenery but also experience the sequence of vegetation stages [22]. All these examples demonstrate vacant land's potential value in terms of the ecosystem benefits it can provide, including all the weeds, insects, and rodents which live together with men: with minimal alterations to aid access and some signposting, many derelict spaces could become educational outdoor centers, taking over from the standard city park, which is too specialized an environment for this purpose [23]. 


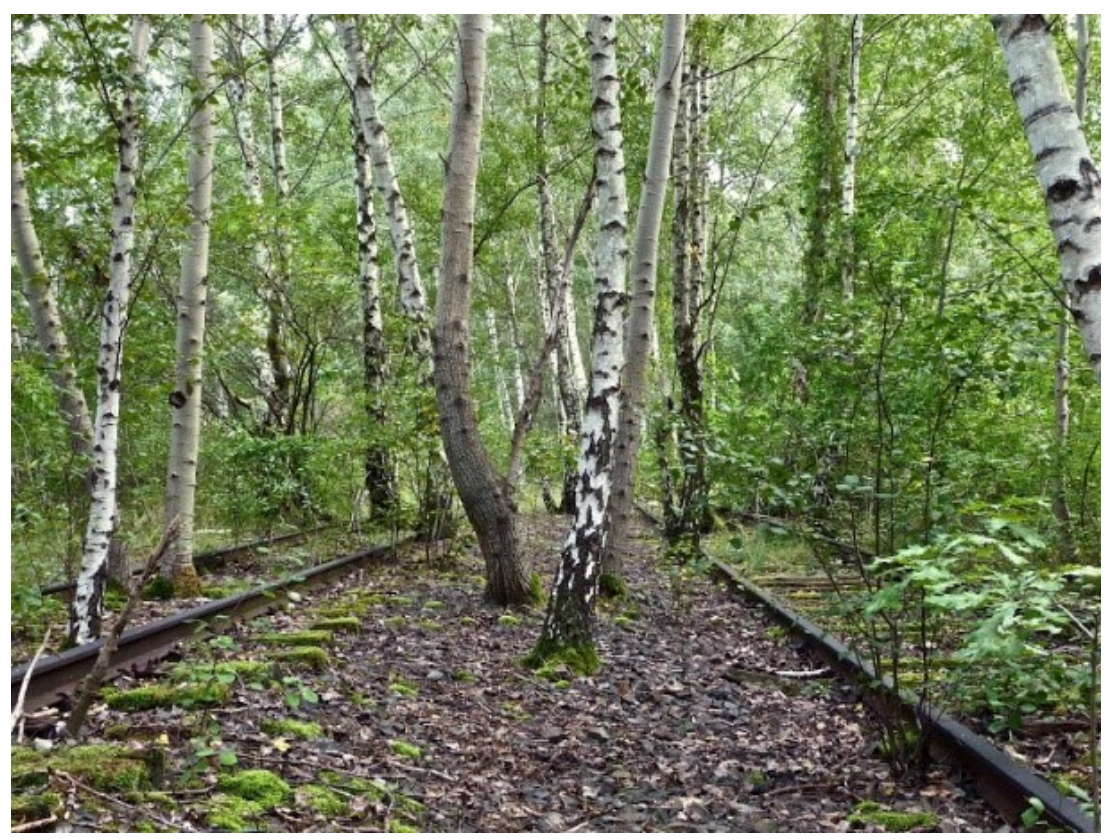

Figure 2. Natur-Park Schöneberger Südgelände, Berlin, Germany (Source: Thorsten Gall, 2011, [21], permission to use granted by: Thorsten Gall (15 May 2016).

\subsection{Greening Vacant Lots}

Recently, a number of cities around the country, including New York, Detroit, Cleveland, Syracuse, Nashville, and Philadelphia, have begun to actively "green" their vacant lots and advance specific open space and stormwater management goals. The City of Philadelphia is one of the most ambitious cities leading the drive to manage stormwater runoff using green infrastructure and thus addressing the EPA's regulatory requirements with their Green City, Clean Waters green stormwater infrastructure plan. The Philadelphia Water Department (PWD) has a goal of filtering or storing the first inch of rain with green infrastructure to reduce the volume of combined sewer overflows [17]. As part of this effort, the city has incorporated vacant lots as part of their urban stormwater management strategy by greening vacant lots as a cost effective way to reduce the amount of rainfall the drains must handle. In many of the successful cases around the country, water agencies are following their lead by greening vacant lots with multi-program goals such as: improving the safety of waterways for fishing and swimming; protecting drinking water supplies; and mitigating the hazardous impacts of flooding [17].

Several cities also have established the goal of using vacant lots as part of their stormwater management strategy. For example, Milwaukee, WI, has redeveloped brownfield sites such as Menominee Valley Industrial Center and implemented a vegetated "treatment train" to capture and filter stormwater runoff from them, while Cleveland, $\mathrm{OH}$, and Detroit, $\mathrm{MI}$, are both planning the greening of vacant lots by issuing Consent Orders. New York City's Staten Island Bluebelt has MS4 permits to manage stormwater and some of Baltimore's Watershed 263 pilot program projects also have MS4 credit. The City of Tallahassee and Leon County, FL, have developed the Capital Cascade Trail to mitigate annual flooding levels and improve the quality of the urban runoff that recharges the state's aquifer, and the New Orleans Redevelopment Authority have developed a project for greening the city's many vacant lots as a cost effective way of reducing the amount of urban stormwater and thus minimizing future FEMA insurance claims [17]. As these examples of cities' plan for greening vacant lots indicate, the high potential of utilizing vacant lots for converting blight to a natural asset that benefits the entire local community is finally being recognized [17] (Table 2).

Greening vacant lots can also improve the air quality and consequently public health, cool the air by counteracting the urban heat island effect and thus reduce demand for air conditioning, and support 
climate change adaptation, all of which promotes the quality of urban life [6,8]. The greening of vacant lots shows how a city can utilize vacant lots as an integral part of their urban green infrastructure system for urban planning that will result in improvements that provide multiple benefits for ecologically underserved communities and regions, while at the same time utilizing green infrastructure on vacant lots to manage and mitigate stormwater and improve the water quality. Current green infrastructure projects on vacant land generally focus on a single purpose of ecosystem services and functions, such as stormwater treatment, but our growing understanding of the multi-faceted services actually provided by green infrastructure on vacant land is beginning to have an impact on urban design properties, particularly with regard to health, sustainability, and social responsibility in ecologically underserved communities and regions.

Table 2. Characteristics of greening vacant lots programs and policies around the country in the U.S. (Source: Crauderueff, R; Margolis, S; Tanikawa, S., 2012, reorganized by author) [17].

\begin{tabular}{|c|c|c|c|c|}
\hline Case & Year & Program & Goals & Planning Strategies \\
\hline New York, NY & 1999 & $\begin{array}{l}\text { Community } \\
\text { Gardens }\end{array}$ & $\begin{array}{l}\text { Provide permanent space } \\
\text { and support to community } \\
\text { gardens. }\end{array}$ & $\begin{array}{l}114 \text { community gardens through Trust for Public Land } \\
\text { (TPL) \& New York Restoration Project (NYRP). More } \\
\text { than } 600 \text { community gardens are registered with Green } \\
\text { Thumb (of over } 1000 \text { citywide). NYRP \& TPL purchased } \\
114 \text { community gardens in } 1999 \text { from the City of New } \\
\text { York, which threatened to develop the sites as housing. } \\
\text { The TPL incubated three local land trusts (Bronx Land } \\
\text { Trust, Manhattan Land Trust, \& Brooklyn Queens Land } \\
\text { Trust) based on community interest. }\end{array}$ \\
\hline New York, NY & 1989 & $\begin{array}{l}\text { Staten Island } \\
\text { Bluebelt }\end{array}$ & $\begin{array}{l}\text { Manage stormwater runoff } \\
\text { in separately sewered area. }\end{array}$ & $\begin{array}{l}\text { Appx. } 400 \text { acres of wetlands, many with public access. } \\
\text { Cost-benefit analyses indicated the Bluebelt system was } \\
\text { more cost-effective than a system relying only on gray } \\
\text { infrastructure }\end{array}$ \\
\hline Detroit, MI & 1989 & $\begin{array}{c}\text { The Greening } \\
\text { of Detroit }\end{array}$ & $\begin{array}{l}\text { Increase vegetative cover } \\
\text { and improve communities in } \\
\text { Detroit. }\end{array}$ & $\begin{array}{l}\text { Appx. } 1400 \text { vacant lots greened and maintained, appx. } \\
1400 \text { family, school, and community vegetable gardens } \\
\text { developed, and } 80,000+\text { trees planted. The urban } \\
\text { reforestation program utilizes GIS to ensure each } \\
\text { planting maximizes ecosystem services, as well as social } \\
\text { considerations. }\end{array}$ \\
\hline $\begin{array}{c}\text { Genesee } \\
\text { County, MI }\end{array}$ & 2002 & $\begin{array}{l}\text { Genesee } \\
\text { County Land } \\
\text { Bank Authority }\end{array}$ & $\begin{array}{l}\text { Acquire, manage \& dispose } \\
\text { of foreclosed properties for } \\
\text { public benefits, including } \\
\text { urban redevelopment and } \\
\text { the greening of vacant lots. }\end{array}$ & $\begin{array}{l}\text { Community gardens, urban agriculture, side yards. } \\
\text { Through Clean \& Green program, Signature Greening } \\
\text { projects demonstrate new greening practices, including } \\
\text { low-maintenance plantings and pocket parks. The Land } \\
\text { Bank works with community organizations \& residents } \\
\text { to identify and prioritize sites to green. }\end{array}$ \\
\hline Milwauke, MI & 1998 & $\begin{array}{l}\text { Menomonee } \\
\text { Valley } \\
\text { Industrial } \\
\text { Center }\end{array}$ & $\begin{array}{l}\text { Redevelop 133-acre } \\
\text { brownfield site for economic } \\
\text { development, and } \\
\text { environment and } \\
\text { community benefit. }\end{array}$ & $\begin{array}{l}\text { A } 30 \text {-acre stormwater treatment train integrated into } \\
\text { a } 40 \text {-acre public park with passive and active } \\
\text { recreational uses, including the trail and space for } \\
\text { environmental education. A } 63 \text {-acre industrial center } \\
\text { with } 8 \text { of } 13 \text { parcels occupied providing } 1100+\text { jobs. }\end{array}$ \\
\hline $\begin{array}{l}\text { Tallahasse \& } \\
\text { Leon County, } \\
\text { FL }\end{array}$ & 1999 & $\begin{array}{c}\text { Capital } \\
\text { Cascade Trail }\end{array}$ & $\begin{array}{l}\text { Mitigate flooding, protecting } \\
\text { drinking water supply, and } \\
\text { improve social well-being of } \\
\text { city \& county. }\end{array}$ & $\begin{array}{l}\text { Greenway with pedestrian and bike lanes, public parks, } \\
\text { interactive cascade fountain, playground, and walking } \\
\text { and fitness trails. Citizen's Economic and Environmental } \\
\text { Consensus Committee developed the proposal with City } \\
\text { \& County agency staff for greening sites throughout the } \\
\text { County. }\end{array}$ \\
\hline
\end{tabular}


Historically, greening vacant lots for neighborhood improvement purposes has been conducted through a variety of policy mechanisms [1]. For example, there is a growing interest in supporting urban agriculture that encourages the planting of food crops on unproductive green spaces to foster food security and provide additional environmental benefits [24,25]. Vacant Lot Cultivation Associations facilitate gardening on vacant land and encourage the poor to grow food for sale and self-consumption [26] and land trust lease and acquisition programs enable communities to maintain gardens [11]. In underserved neighborhoods, Cooperative Extension support for food production [26] operate side-lot or "abutter" programs that encourage residents to manage the land between buildings, as well as a more recent integration of community garden and urban agriculture programs that is contributing to the creation of more sustainable planning processes [27-29].

These projects, all of which focus on the transformation of vacant land, are components of urban community comprehensive plans that also include waterfront park development, the developments of greenways along railroads or post-industrial abandoned sites for bike and pedestrian pathways, and the creation of city gateways [11,30,31]. Cities that have extensive experience of land abandonment, such as Baltimore, MD, Cleveland, $\mathrm{OH}$, St. Louis, MO, and Flint, MI, have used vacant land by aggregating sites for productive uses or by creating open and green spaces with the aid of government or quasi-governmental land banks [32-34]. Green spaces provide numerous additional benefits, such as improving air quality and public health, cooling the air, reducing the demand for air conditioning in hot weather, and supporting climate change adaptation [35].

The literature review of greening vacant lots suggests that vacant land supports many different types of ecosystem services and the benefits obtained depend on the environmental conditions, uses, and management practices involved; where natural systems are established through ecological succession or intentional human intervention, ecosystem services are produced [1]. Vacant land does indeed contribute substantially to ecosystem services and the resulting benefits for local communities, and could potentially contribute more if managed appropriately [36] (Table 3).

Table 3. Greening options for vacant lots (Source: Schilling, J.M.; Mallach, A. 2012, reorganized by author) [36].

\begin{tabular}{|c|c|c|}
\hline Vacant Land Type & Potential Green Reuse & Description \\
\hline \multirow{6}{*}{$\begin{array}{l}\text { Small-moderate-size } \\
\text { scattered lots in viable } \\
\text { neighborhoods }\end{array}$} & Park expansion & Adding parcels of land to existing \\
\hline & Side lots & $\begin{array}{l}\text { Sale of lots to adjacent home owners to permit expansion of } \\
\text { owner's lot }\end{array}$ \\
\hline & Stabilization/minimal treatment & $\begin{array}{l}\text { Basic treatment and maintenance to provide attractive } \\
\text { environment and minimize blighting effects }\end{array}$ \\
\hline & Pathways & Midblock or multiple pedestrian and bicycle paths \\
\hline & Mini-parks & Small playgrounds and passive parks for use by neighbors \\
\hline & Community gardens & Small gardens supported by residents of neighborhood \\
\hline \multirow{8}{*}{$\begin{array}{l}\text { Large parcels in largely } \\
\text { disinvested areas }\end{array}$} & Stormwater management & Restoring buried natural stream \\
\hline & Low-intensity open space & $\begin{array}{l}\text { Re-creation of meadows, woodlands, and other } \\
\text { sustainable uses }\end{array}$ \\
\hline & Greenways & Linear green spaces providing for pedestrian and bicycle use \\
\hline & Alternative energy production & $\begin{array}{l}\text { Using land for renewable energy production such as solar, } \\
\text { wind, or geothermal energy }\end{array}$ \\
\hline & Urban farms & $\begin{array}{l}\text { Larger-scale agriculture activities designed to provide } \\
\text { commercial products }\end{array}$ \\
\hline & Stabilization/minimal treatment & $\begin{array}{l}\text { Basic treatment and maintenance to provide attractive } \\
\text { environment and minimize blighting effects }\end{array}$ \\
\hline & Stream daylighting & Restoring buried natural streams \\
\hline & Alternative energy production & $\begin{array}{l}\text { Using land for renewable energy production such as solar, } \\
\text { wind, or geothermal energy }\end{array}$ \\
\hline
\end{tabular}




\subsection{Vacant Land as Public Open Space}

Vacant land presents an alternative to contemporary public spaces because even when vacant land is privately owned, local people have easy access and it can thus accommodate a variety of social groups, including marginalized types, creative industries and artists, or just young people hanging around in a place where they feel less under public scrutiny, and families with kids enjoying some contact with nature that does not cost a fortune [18]. Research suggests that external space is perceived as "public" when it is easy to access; its ownership or management is irrelevant [37]. Public space does not require high costs or impressive design, but rather space for people's activities, enabling them to enjoy social interactions that certain types of public spaces encourage, even if some public spaces do not have remarkable design, or are untidy and self-regulated places, such as street markets [38,39]. Vacant land provides adventure playgrounds [18] and is generally favorable for constructing, adapting, and destroying and growth cycles, hence welcoming woody scrubland and activities such as climbing a tree, playing in tall grass, playing hide and seek among bushes, and picking and tasting leaves, flowers or berries, all of which encourage children to take control over their environment [40,41].

Gillespie Park in the UK acts as just such a social and natural hub, providing a visitor and education center that is visited by large numbers of schoolchildren and holding a community festival once a year with over 2000 people attending [19]. It provides opportunities for people to engage in cultural activities, such as blackberry picking, or decorating the trees with jewelry, prayers, and other objects [42]. Vacant land can accommodate a wide range of different activities that are not typically permitted in official public spaces, such as skateboarding, graffiti making, and dirt biking, as well as community gardens and urban agriculture [18]. Vacant land can also provide creative uses such as, for instance, farmer's markets and garage sales, all of which add color and life to neighborhoods, with activities that could deliver local skills and products which outlive the sites and remain as a long-term legacy [43]. In other cases, the reuse of post-industrial sites occurs for commercial, artistic, athletic, leisure, and community activities, with permission from owners and planning authorities, but with a limited amount of renovation for longer-term or more organized forms of occupancy [44]. As a result, the social dimension of vacant land matches that of "loose space", describing people's experience of unofficial spontaneous activities in public spaces in order to appropriate them [44].

Vacant land also contributes to open space in dense city areas, where it provides a resting area, important distant views, and a visual connection with other parts of the city in a way that is more effective than other densely planted parks or woods areas [18]. Open space is an important component of the built environment as a "void" physical form that provides openness for accessibility in the city mass. In psychological terms, openness is associated with freedom, a loosening of control and regulation, adventure, and play [18]. As part of a city-wide network, vacant land also provides different types of open space that "extend choice" from the "approved formal garden and manicured park" and also provides walking, bicycle, or riding trails, generating an alternative way of exploring and learning about the city and its ecology [23].

\subsection{Vacant Land as Community Garden}

Philadelphia has devoted considerable effort to rediscovering vacant land as a resource for social benefit. The city has tens of thousands of vacant parcels and abandoned structures and the Pennsylvania Horticultural Society (PHS) is one of the leaders in the "rethinking vacant land" movement. The Philadelphia greening program not only focuses on converting vacant lots into community gardens, but also hopes to awaken community spirit and commitment [10] in the form of community engagement. During the process of caring for community gardens, residents are able to develop strong relationships with their neighbors and consequently feel more attachment to their community. Jane Schukoske stated that community gardens build social capital not only by reclaiming or preserving urban space, but also by fostering collaboration among nearby residents across racial and generational lines [45]. 
To achieve this goal, Philadelphia introduced multi-sector collaborations with the Philadelphia Water Department (PWD), the Philadelphia Parks and Recreation Department (PPR), and the Pennsylvania Horticulture Society (PHS) to manage the greening program, and a land bank run by a non-profit organization. PHS's Philadelphia LandCare (LandCare) program was created to acquire, manage, and dispose of the vacant land [17]. The Philadelphia Redevelopment Authority (PRA) provides a "one-stop shop" to coordinate the transactions related to vacant land owned by the Philadelphia Department of Public Property, the Philadelphia Housing Development Corporation, and the PRA [46]. This close collaboration between multiple agencies, including governmental organizations, nonprofit organizations, and community organizations are essential elements of the city's plan to manage vacant lots in the City of Philadelphia.

PWD works closely with civic groups, watershed partnerships, neighborhood organizations, and the City Council to identify and prioritize the greening of vacant lots in the city. It also works with other planning bodies, such as the Planning Commission, PPR, and the Mayor's Office of Transportation and Utilities [17]. PHS's Philadelphia LandCare program converts vacant lots to green, clean spaces with the goal of improving and stabilizing neighborhoods by cleaning up vacant lots and bringing in topsoil, planting grass, surrounding the lot with a three foot high post and rail fence, and maintaining the green spaces created. PHS has strong partnerships with numerous community groups and maintenance of the sites is carried out by landscape contractors. The Neighborhood Garden Association in the same city is a land trust that owns several community gardens, but it has not expanded its role due to the limited funding available [17].

There are similar community garden programs in a number of other U.S. cities. In the 1980s, Boston's Dudley Street neighborhood was suffering from problems due to its high percentage of vacant properties, about $21 \%$ of all property [10]. However, the area has now dramatically improved as a result of the creation of a community land trust to manage the vacant land as gardens. This approach is becoming very popular; for instance, Atlanta has its Community Gardening Initiative; Chicago has established Greencorps; and New York operates a Green Thumb program [10].

Atlanta Regional Commission inaugurated its Senior Community Garden Initiative in 2010, establishing 11 community gardens and providing nutrition education and cooking classes with the goal of encouraging seniors to have healthier lifestyles by increasing their access to fresh fruits and vegetables, as well as providing opportunities for elderly people to engage in more social interactions [47]. This community garden is supported by multiple agencies, including the Federation of Southern Cooperatives Land Assistance Fund, University of Georgia Cooperative Extension, Open Hand, and the Aging Network. The Federation of Southern Cooperatives support planning, planting, and sustaining the community gardens and each garden is funded by seed money, which supports garden soil and soil amendments, lumber and other supplies for the beds and structures needed to support the garden, plants and seeds, gardening tools, watering hoses, and other irrigation equipment. The benefits of community gardens include improving the quality of life for people in the garden and providing a catalyst for neighborhood and community development [47].

Greencorps in Chicago provides green industry jobs that include training for practical experience, academic enhancement, and professional development in a variety of environmentally-related jobs that involve skills such as horticulture, urban agriculture, tree care, landscaping, carpentry, ecological restoration, Integrated Pest Management (IPM), and many other specialties [48]. Greencorps Chicago maintains and restores natural and public spaces that are safe, healthy, and sustainable, to promote environmental stewardship and improve the quality of life for local residents. Public and private partnerships, along with strong government support, are the important elements contributing to the success of this project, and the outcome is healthier and safer, and has more engaged communities and individuals who can experience environmental stewardship through their field of experience and train for a variety of environment-related jobs [48]. The training is delivered in cooperation with the Chicago Park District, The Forest Preserve District of Cook County, and other public and community partners. 
New York City's Green Thumb program is the largest community gardening program in the nation. Due to the many private and public lots that were abandoned during the city's financial crisis in the 1970s, the Green Thumb program was created to renovate derelict land using volunteers [49]. The community gardens provide important green spaces, thus improving air quality, bio-diversity, and the social well-being of residents. The gardens are also important community resources and the Green Thumb program provides technical and material support to over 600 community gardens in New York City. Workshops are held every month to teach basic gardening skills, along with more advanced farming and community organizing topics [49].

Nationwide, there were estimated to be over 350 community gardening programs in 1995 [50] and this number is doubtless now considerably higher. However, the success of community garden programs has resulted in another problem. As community gardens on vacant land become popular, the potential for development is also increased. For example, in 2002, New York City announced plans to sell 131 gardens for development as affordable housing sites [51]. As a result, community activists and gardeners protested the proposal until city officials provided a more acceptable alternative plan for community gardens. Community garden preservation was not simply the flowers and vegetables grown in the gardens but also the social connection created by their presence [10]. Caring for the vacant land is another form of ownership that increases people's engagement to vacant land and also promotes neighborhood identity.

\subsection{Economic Benefits of Vacant Land}

The physical blight of vacant land contributes to the vicious cycle of disinvestment shown in Figure 3, further reducing reinvestment and development, as vacant land conveys negative images that deter potential investment and thus increases urban vacancy rates [52]. Vacant land deters investment but imposes costs on the local community and public sector agencies to maintain vacant properties, while at the same time discouraging investment from the private sector [17]. For example, vacant land has been shown to decrease property values by $20 \%$ and cost the city of Philadelphia $\$ 20$ million each year for maintenance alone. In addition, 17,000 of the city's 40,000 vacant parcels are tax delinquent, 11,000 of them for more than 10 years. As a result, the city is losing a minimum of $\$ 2$ million in revenue annually [53].

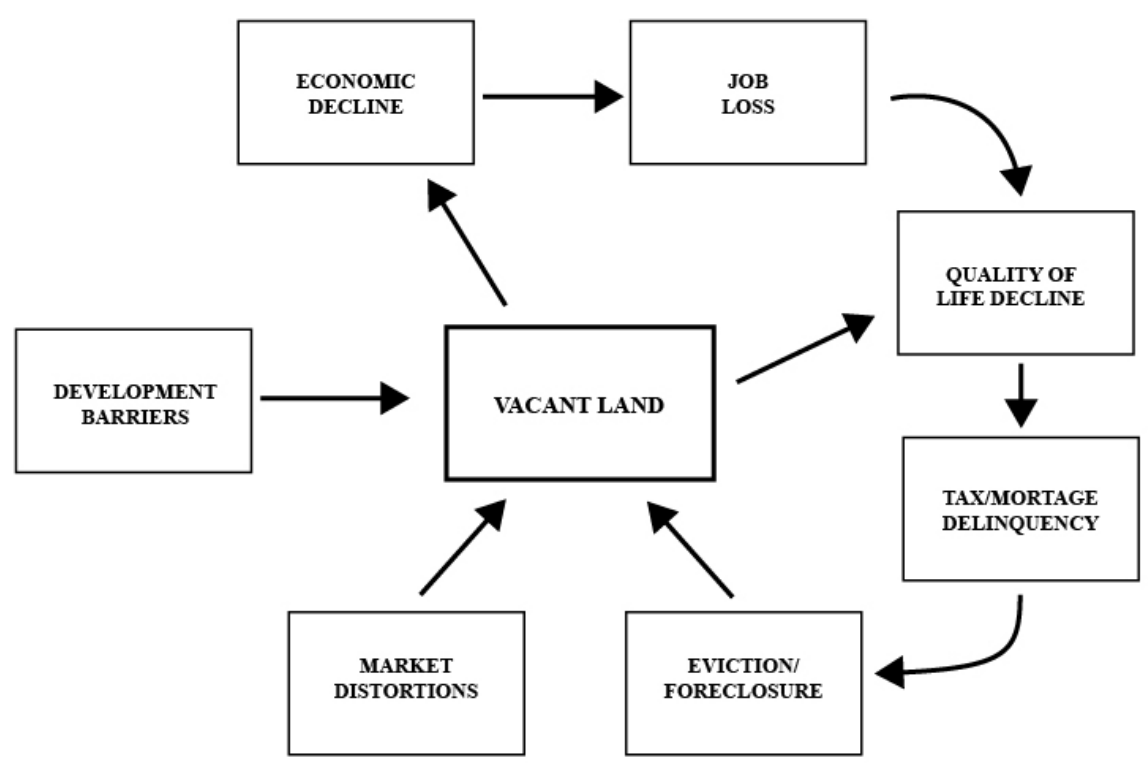

Figure 3. The vicious cycle of decline (Source: Goldstein, J.; Jensen, M.; Reiskin, E., 2001, [52]), permission to use granted by: James Goldstein (16 May 2016). 
However, Philadelphia Horticultural Society (PHS) program of greening vacant lots is promoting environmental and social wellbeing and also supporting economic development. According to EPA's Consent Order, the City of Philadelphia plans to invest $\$ 1.2$ billion in a green infrastructure system to manage urban stormwater management over the next 25 years. This plan aims to capture the first inch of rain in a green infrastructure that covers approximately one-third of the existing pervious land in the city's combined sewage drainage areas [54]. Approximately, $60 \%$ of Philadelphia has combined sewers [55], so if the plan succeeds, the city can effectively control very large amounts of urban stormwater. The city has also developed a land bank to focus on the acquisition, management, and disposition of vacant land for its Green 2015 plan, which aims to increase public open space by 500 acres by 2015. As part of this effort, the Pennsylvania House Bill 1682 was signed into law on 24 October 2012, to allow municipalities in the state to create land banks to manage vacant lots [56]. According to a study by Penn Praxis (2010), although 200,000 Philadelphians do not live within a half a mile of public green space, the researchers identified 558 acres of publically owned vacant lots at least one quarter of an acre in size, and a further 1257 acres of privately owned vacant parcels larger than one quarter of acre [57]. This suggests that these vacant parcels have the potential to be transformed into public green space to achieve the goal of PPR's Green 2015 Plan to provide additional green space benefits.

Research indicates that the Pennsylvania Horticultural Society (PHS) program of greening urban vacant land has significantly improved the economic and social well-being of local neighborhoods by encouraging reinvestment. There has also been a statistically significant decrease in gun violence in these neighborhoods over a ten-year time frame [58]. An economic study by the Philadelphia Redevelopment Authority (PRA) estimated that homes within one quarter of a mile of one of PHS's greened vacant lots has increased in value by $2 \%$ to $5 \%$ annually, equivalent to $\$ 35,000$ over five years, generating an additional $\$ 100$ million in annual property taxes for the city. The study estimated that each public dollar invested in the LandCare clean and green program returns $\$ 7.43$ dollars of tax revenue [59].

\section{Implications for Urban Vacant Land}

In the future, broad policy approaches and programs will dominate effort to alter the structure of different types of vacant land, and the nature of the vacant land will be a major determinant of its potential utility. Implementation strategies for urban vacant land are described in the following section.

\subsection{Vacant Land Typology}

Depending on the previous and current urban vacant land use structure, the existing condition and redevelopment potential of a piece of vacant land may vary considerably and will thus require one of a number of different approaches for future development. Urban vacant land has different characteristics, and it is important to understand the different potentials and obstacles to the redevelopment of these spaces [60]. Therefore, a typology of vacant land will help planners and designers to understand and plan for urban vacant land, leading to better utilization of these spaces and opening up alternative creative approaches to envisioning space and landscape design in a city.

The urban vacant land typology presented here was designed by the author as a tool to be used for planning and designing vacant parcels in terms of enhancing the ecological and social benefits they provide. The typological approach to vacant land lends itself to the categorization of project-appropriate vacant land into five types: post-industrial sites, derelict sites, unattended sites with vegetation, natural sites, and transportation-related sites (Table 4). The typology of vacant land proposed here is not expected to serve as an absolute typological framework for categorizing vacant land, but instead is intended to assist designers, planners, and municipalities dealing with urban vacant land. Each can benefit from systematic approaches that build on the relationships among the types, providing not just a new approach based on an integrated system for assessing vacant land's multiple benefits, but also incorporating a constellation of practices and urban features that can be 
implemented to maximize the social, aesthetic, and environmental values gained, all of which have significant impact on the health and quality of life in ecologically underserved cities and regions.

Table 4. Categories of vacant land.

\begin{tabular}{|c|c|c|c|}
\hline Category & Image & Example & Characteristic \\
\hline Derelict sites & & $\begin{array}{l}\text { Building or house remains empty or unused. } \\
\text { Previously developed land that is now vacant } \\
\text { and often wasted or unused sites: e.g.,) } \\
\text { unsafe, place for illegal activity, abandoned } \\
\text { buildings or structures }\end{array}$ & $\begin{array}{l}\text { Size: } 136 \mathrm{~m}^{2} \\
\text { Ownership: Unknown } \\
\text { Zoning: R-7 (residential } \\
\text { single-family district) } \\
\text { Tree number: } 61.8 \text { per ha } \\
\text { Contamination: None }\end{array}$ \\
\hline Natural sites & & $\begin{array}{l}\text { The sites have physical constraints by } \\
\text { environment conditions: e.g.,) drainage areas, } \\
\text { wetlands, hillsides, river banks / river } \\
\text { flood plains }\end{array}$ & $\begin{array}{l}\text { Size: } 10,521 \mathrm{~m}^{2} \\
\text { Ownership: Municipal } \\
\text { Zoning: ROS (recreation } \\
\text { and open space district) } \\
\text { Tree number: } 90.1 \text { per ha } \\
\text { Contamination: None }\end{array}$ \\
\hline
\end{tabular}

Source: Vacant land typology images were taken by author during field observation and measurement in central Roanoke River. Data for size, ownership and zoning of each vacant lot were collected from Roanoke GIS vacant land parcel information (http:/ / www.roa-nokecountyva.gov/FormCenter/GIS-4). Data for tree number was collected form i-Tree Eco sampling during 2013 and contamination level was collected from the Environmental Data Resources (EDR's) comprehensive survey [60].

Different types of urban vacant lands can be categorized in terms of their potential uses. Figure 4 outlines the various types of urban vacant lands and their characteristics, derived from the field observations. Depending on its development history, urban vacant land can be divided into previously developed land or previously undeveloped land. Previously developed land often, but not invariably, has existing building structures, while previously undeveloped land represents sites that have never been built on and so contain no remnants of building structures. Depending on the contamination level, history, and the quality of the vegetation on the site, previously developed land may be suitable for limited or unlimited development, ecosystem conservation and limited use, and both active and passive historically appropriate use. Previously undeveloped land is more straightforward: it is either suitable for development, or not suitable for development, depending on whether its natural and physical characteristics render it physically unfit for development. Depending on the quality of vegetation on the site, previously undeveloped land may be suitable for environmentally sensitive use, unlimited development, ecosystem conservation, and ecosystem enhancement (Figure 4).

For example, vacant parcels often contain unimproved natural forests consisting of diverse species of trees, shrubs, and ground covers in natural stand conditions, generally because there has been no development pressure on natural resources. The natural stand vegetation structures on 
vacant land have higher species diversity relative to other land uses. Greater species diversity helps natural sustainability, thus providing a healthy ecosystem that can better withstand and recover from a variety of natural hazards [61]. The vacant land can thus be used as green infrastructure that significantly improves the health of urban ecosystems and provides enduring value for the community. This suggests that the high ecosystem values of "unattended sites with vegetation" could be acknowledged and protected. Thus, if these sites are developed, it could be done in a manner that protects their current ecosystem values. Less sensitive "post-industrial" and "derelict sites" that have lower ecosystem values could be given priority for development for different types of land use (e.g., housing, commercial, industry and green re-use options) that have the greatest potential for increasing ecosystem benefits. Those "post-industrial" and "derelict sites" with historical significance that have remediation potential could be developed in a manner that preserves their historical value with a historically appropriate use. If other "natural sites" and "transportation-related sites" have low ecosystem values and are not threatened by development, their current low ecosystem values have the potential to be enhanced through proper management. 
Urban vacant land typology

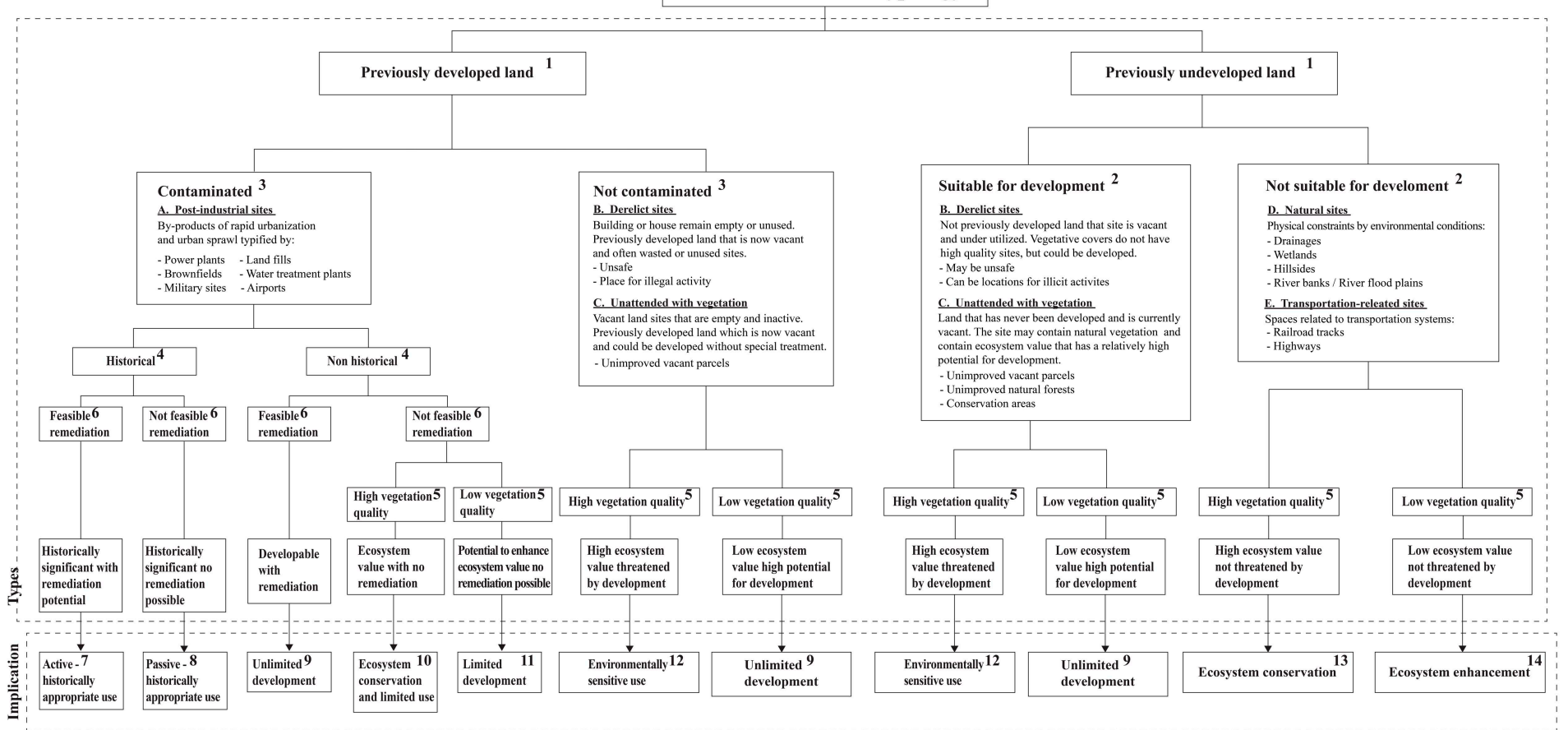

Foot notes
Types defenition:

Previous development history 1 : Land use development history

列

unfit for development.
onatmination level is based on the vacant land's current physical condition and assumend previous land-use history.

Historical site4: Historical significance based on the historical event or structure.

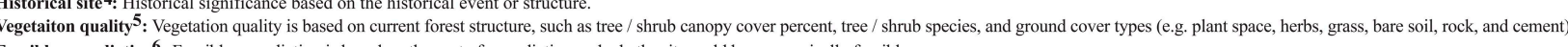
Feasible remediation 6 : Feasible remediation is based on the cost of remediation and whether it would be economically feasible.

Implication defenition:

作

Passive - historically appropriate use: Site is contaminated and should be preserved historically, but with use limited to avoid human contact with pollution

Unlimited development $\%$ : Site should be eredeveloped for many different types of land-use (e.g. housing, commercial, industry and green re-use options).
Ecossstem conservation and limited use $\mathbf{~}^{0}$ : Site should be developed in uses that conserve ecosystem values and provide safe level of human contact with pollution

Ecosystem enhancement ${ }^{14}$ : The current low ecosystem value needs to be enhanced

Figure 4. Typology of urban vacant land. 


\subsection{Planning Policies}

Although few are familiar with the reuse of vacant land in terms of its ecological and social value, financial issues are major obstacles for redevelopers of vacant land. Most cities lack adequate economic incentives designed to support vacant land and abandoned buildings that could be maintained and improved. Tax foreclosures and enforcement codes increase the already large amounts of vacant land that is not maintained for lengthy periods of time. Unmaintained vacant land and abandoned buildings negatively impact both local property values and the quality of life in surrounding neighborhoods. Maintenance has value in itself, which can encourage redevelopment in the future. Municipalities should provide vacant land investment policies, such as tax incentives, tax credits, and rehabilitation abatement on vacant land and abandoned buildings. Without financial investment, stabilizing neighborhoods is difficult or impossible. Government regulatory strategies, such as enforcement codes on vacant land, could help control these problems; vacant property enforcement codes could include maintenance requirements and registration fees for vacant properties to encourage the owners to improve their properties and make their surroundings secure.

For private development of vacant land and abandoned buildings, it may be helpful if municipalities provide some incentives, such as tax abatement for infill projects areas with vacant land. Encouraging investment in homes and neighborhoods by residents and owners, and increasing home ownership rates is ultimately the best way to establish neighborhood stability [36]. Hence, since a city is unlikely to be able to afford to redevelop all its vacant land, the private market must be encouraged to acquire and reuse vacant land where possible. Vacant land forest structure tax credits can also be a useful tool, especially where it would be beneficial to preserve the structure of vacant land. When people develop on natural stand vacant land, they can redevelop abandoned buildings and other empty spaces, but vacant land forest structures are healthier and so more valuable compared to other vacant land types [6]. By protecting the existing vacant land forest structure, owners receive utility tax credits, and thus save on water utility costs. For both short-term and long-term uses, one policy that has been found to encourage development is a tax system that collects a higher proportion from land value than from the value of improvements (buildings) [62]. By dropping the relative tax penalty for land development, owners are less likely to consider their vacant land as their primary asset, and unproductive speculation can be reduced [10]. A graded property tax system promotes restructuring residential vacant land by requiring that the land is maintained, thus encouraging redevelopment. Well-maintained vegetative structures affect both the property value and the quality of life in the surrounding neighborhood; cleaning and maintaining the land raises property values and hence increases tax receipts. If owners fail to maintain their vacant land, the city can enforce vacant land maintenance enforcement codes using fines and liens [62].

Implementing an approach that draws on typology will support the efforts of government officials to create different policies, programs, and regulations for different types of vacant urban land. Local, state, and federal government agencies should create program goals for vacant urban land encouraging the following: (1) post-industrial sites could become integral parts of public amenities such as urban parks to build the city image through their rehabilitation for long-term uses; (2) derelict sites could become valuable community assets, along with unattended with vegetation sites, as part of the city's stormwater control program and to improve local air quality; and (3) natural and transportation-related sites could become part of a city-wide green network system for long-term uses.

A lead agency, such as a city planning agency, city community development agency, economic development corporation (CDC), or special purpose or special district public entity, should be specifically designated to play a key role in advancing redevelopment plans for different types of vacant urban land to support the design, implementation, and maintenance of site-specific green infrastructure. Using Geographic Information System (GIS) may help planners to identify neighborhood brownfield areas such as post-industrial sites, stabilize areas that are derelict or unattended with vegetation, and optimize the potential and site aggregation of green networks and natural and transportation-related sites. Special programs and new organizations that manage different types of vacant land should 
be created, using project funding from special tax levies, family foundations, personal funds, and endowments from private donations for financial improvement and maintenance.

In addition, multiple goals should be created for transforming different types of vacant land into green infrastructure to promote neighborhood stabilization and economic well-being, as well as to improve the community's quality of life through multiple public uses of the green infrastructure created. State and federal governments should create a lead agency, such as a land bank, that has a long-term planning and implementation capacity to acquire post-industrial sites, aggregate sites that are derelict, sites that are unattended with vegetation, and natural and transportation-related sites, through multiple acquisition strategies, such as eminent domain, the threat of eminent domain, or intergovernmental transfer and interim ownership of different types of vacant land until construction is completed or local government can pay for the properties.

\subsection{Maintenance}

City governments should also support the public maintenance of different types of vacant land by multiple city and county agencies through funding supplied from ratepayer fees for post-industrial sites, building maintenance codes from local ordinances to maintain minimum safety standards, enforcing abandoned property maintenance requirements, and charging vacant lot registration fees for sites that are derelict or unattended with vegetation to support the provision of maintenance staff to care for green networks on natural and transportation-related sites. Government agencies should also support the private maintenance of different types of vacant land by providing: green infrastructure credits for environmental benefits and human health and well-being from public sectors for post-industrial sites; neighborhood residents trained as inspectors for the sites that are derelict or unattended with vegetation who can issue warning notices regarding violations of the city's property maintenance code; official enforcement action to improve the sites that are derelict and unattended with vegetation, if necessary; and public sector incentives to provide a certain percentage of stormwater credit through easements to natural and transportation-related sites for their ecosystem conservation or ecosystem enhancement. City governments should support the community volunteers who maintain the sites that are derelict or unattended with vegetation, as well as the natural and transportation-related sites for their ecosystem conservation or enhancement by outside greening organizations and land trusts for short-term and long-term uses of different types of vacant land. Youth summer employment schemes should be supported through land banks and clean and green programs, as well as green crops initiatives that provide employment maintaining different types of vacant land.

\section{Conclusions}

Urban vacant land is a common sight in most cities today and it has become a normal part of the urban fabric. However, due to a lack of public interest, policy, and economic investment, much of our urban vacant land has become a wasteland that is both underused and under-appreciated. This study demonstrates how urban vacant land can function as green infrastructure that provides ecosystem services and social values for the local community. Urban vacant land is not normally thought of as green infrastructure, partly because the potential ecological and social benefits provided by these spaces are not widely recognized. Rather, it is generally viewed only from an economic perspective of its highest and best use and so sits neglected, waiting until it is economically viable to develop it. However, in spite of appearances, vacant land does contribute ecosystem services and social benefits even as it is, and could potentially contribute far more if managed appropriately. The findings of this research address some of the gaps in our knowledge of the potential public value in terms of ecological and social benefits provided by urban vacant land and its capacity to assist in the future design, planning, and management of the vacant land in our cities. This demonstration of the public value of urban vacant land based on its ecological and social characteristics is a particularly useful way to consider its value in the urban landscape, and understanding the role of vacant land as a potentially 
valuable natural and community asset for short-term and long-term uses can promote decision-making that will improve human health and environmental quality in the surrounding neighborhood.

The results of this study can be used to identify specific ecological and social benefits that can be provided by vacant land in our cities, which have the potential to improve urban policies through the creative planning and the management of vacant land, as well as providing information to support the inclusion of the ecological value of vacant land within existing environmental regulations, showing how vacant land affects the environment and, consequently, enhances human health and the environmental quality in urban areas. The significance of this research is the new vision it provides of urban vacant land as a valuable ecological and social resource, demonstrating how it can be used to enhance ecosystem health and promote a better quality of life for city residents. By utilizing such sites more effectively, urban vacant land can supplement the range and variety of the urban open spaces that are available for city residents. The study's findings thus provide useful information for urban planners, architects, landscape architects, and other design professionals concerned with the design and planning of the urban landscape by encouraging them to treat vacant land as a valuable resource that can be utilized to create new open space opportunities for city residents. Overall, this study will serve as a useful reference for local authorities, landowners, and urban regeneration professionals, as well as highlighting the need to change our current approach towards valuable urban vacant land.

Acknowledgments: This research was supported by funds through the APS Endowment for Sustainable Design Research Fund (Arizona State University, Herberger Institute for Design and the Arts).

Conflicts of Interest: The author declare no conflict of interest.

\section{References}

1. Kremer, P.; Hamstead, Z.A.; McPhearson, T. A social-ecological assessment of vacant lots in New York City. Landsc. Urban Plan. 2013, 120, 218-233. [CrossRef]

2. Jakle, J.A.; Wilson, D. Derelict Landscapes: The Wasting of America's Built Environment; Rowman \& Littlefield: Savage, MD, USA, 1992.

3. Coleman, A. Dead space in the dying inner city. Int. J. Environ. Stud. 1982, 19, 103-107. [CrossRef]

4. Burkholder, S. The new ecology of vacancy: Rethinking land use in shrinking cities. Sustainability 2012, 4, 1154-1172. [CrossRef]

5. Little, G.M. 629 Main Street-A Revisioning of an Urban Void: An Exploration into Challenging Cultural Perceptions of an Urban Vacant Lot; The University of Manitoba: Manitoba, Canada, 2008.

6. Kim, G.; Miller, P.A.; Nowak, D.J. Assessing urban vacant land ecosystem services: Urban vacant land as green infrastructure in the City of Roanoke, Virginia. Urban For. Urban Green. 2015, 14, 519-526. [CrossRef]

7. Németh, J.; Langhorst, J. Rethinking urban transformation: Temporary uses for vacant land. Cities 2014, 40, 143-150. [CrossRef]

8. Kim, G.; Miller, P.A.; Nowak, D.J. The value of green infrastructure on vacant and residential land in Roanoke, Virginia. Sustainability 2016, 8, 296. [CrossRef]

9. Pagano, M.A.; Bowman, A.O.M. Vacant Land in Cities: An Urban Resource; Brookings Institution, Center on Urban and Metropolitan Policy: Washington, DC, USA, 2000.

10. Bowman, A.O.M.; Pagano, M.A. Terra Incognita: Vacant Land and Urban Strategies; Georgetown University Press: Washington, DC, USA, 2004.

11. Bonham, J.B.; Spilka, G.; Rastorfer, D. Old Cities/Green Cities: Planning Advisory Service Report Number 506/507; American Planning Association: Chicago, IL, USA, 2002.

12. Millennium Ecosystem Assessment. Ecosystems and Human Well-Being: Synthesis. World Health; Island Press: Washington, DC, USA, 2003.

13. Yadav, P.; Duckworth, K.; Grewal, P.S. Habitat structure influences below ground biocontrol services: A comparison between urban gardens and vacant lands. Landsc. Urban Plan. 2012, 104, 238-244. [CrossRef]

14. Grewal, S.S.; Cheng, Z.; Masih, S.; Wolboldt, M.; Huda, N.; Knight, A.; Grewal, P.S. An assessment of soil nematode food webs and nutrient pools in community gardens and vacant lands in two post-industrial American cities. Urban Ecosyst. 2011, 14, 181-194. [CrossRef] 
15. Shuster, W.D.; Dadio, S.; Drohan, P.; Losco, R.; Shaffer, J. Residential demolition and its impact on vacant lot hydrology: Implications for the management of stormwater and sewer system overflows. Landsc. Urban Plan. 2014, 125, 48-59. [CrossRef]

16. Robinson, S.L.; Lundholm, J.T. Ecosystem services provided by urban spontaneous vegetation. Urban Ecosyst. 2012, 15, 545-557. [CrossRef]

17. Crauderueff, R.; Margolis, S.; Tanikawa, S. Greening Vacant Lots: Planning and Implementation Strategies; The Nature Conservancy: New York, NY, USA, 2012.

18. Kamvasinou, K. The public value of urban vacant land. Proc. ICE Munic. Eng. 2011, 164, 157-166. [CrossRef]

19. GLA (Greater London Authority). (GLA, Mayor of London) London Wildweb, Gillespie Park. 2010. Available online: http://wildweb.london.gov.uk/wildweb/PublicSiteViewFull.do?pictureno=1\&siteid= 75569 (accessed on 22 March 2016).

20. Haringey Council. Parkland Walk Local Nature Reserve; 2010. Available online: http://www.haringey.gov.uk/ index/community_and_leisure/greenspaces/parks_and_open_spaces_parks_facilities/parklandwalk. htm (accessed on 18 December 2015).

21. Gall, T. Natur-Park Schöneberger Südgelände, Berlin, Germany 2011. Available online: https://plus.google.com/103573146092143554342/about?gl=us\&hl=en\&pid=5958908374459861074\&oid= 109759920116080534952 (accessed on 14 May 2016).

22. Grosse-Bächle, L. Strategies between intervening and leaving room. In Wild Urban Woodlands; Kowarik, I., Körner, S., Eds.; Springer: Berlin, Germany, 2005; pp. 231-246.

23. Lynch, K. The openness of open space. In City sense and city design: Writings and projects of Kevin Lynch; Banerjee, T., Southworth, M., Eds.; The MIT Press: Cambridge, MA, USA, 1995; pp. 396-412.

24. Hodgson, K.; Campbell, M.C.; Bailkey, M. Urban Agriculture: Growing Healthy, Sustainable Places; American Planning Association: Chicago, IL, USA, 2011.

25. Ackerman, K. The Potential for Urban Agriculture in New York City: Growing Capacity, Food Security, E Green Infrastructure; Urban Design Lab at the Columbia Earth Institute: New York, NY, USA, 2012.

26. Lawson, L.J. City Bountiful: A Century of Community Gardening in America; University of California Press: Berkeley, CA, USA, 2005.

27. Mayor's office of Sustainability. Greenworks Philadelphia: 2010 Progress Report. Philadelphia, PA, USA, 2010. Available online: http://www.phila.gov/green/greenworks/2010-progress-report.html (accessed on 12 May 2016).

28. Colasanti, K.; Hamm, M.W. Assessing the local food supply capacity of detroit, Michigan. J. Agric. Food Syst. Community Dev. 2010, 1, 41-58. [CrossRef]

29. Seattle Department of Neighborhoods. P-Patch Community Gardening Program. Available online: http://www.seattle.gov/neighborhoods/ppatch/gardening.htm (accessed on 5 September 2015).

30. City of Pittsburgh. Greening Resources. 2012. Available online: http://www.pittsburghpa.gov/ neighborhoodinitiatives/greenup/resources.htm (accessed on 19 June 2015).

31. The Greening of Detroit. Urban Agriculture and Open Space. 2012. Available online: http:/ / detroitagriculture.met/open-space-stories / (accessed on 7 May 2016).

32. Alexander, F.S. Land Bank Authorities: A Guide for the Creation and Operation of Local Land Banks; Local Initiatives Support Corporation: New York, NY, USA, 2005; Available online: http://www.nhc.org/media/files/Land_ Bank_Authorities-Alexander.pdf (accessed on 18 December 2015).

33. U.S. Department of Housing and Urban Development. Revitalizing Foreclosed Properties with Land Banks; Diane Publishing: Collingdale, PA, USA, 2009.

34. Wachter, S.; Scruggs, G.; Voith, R.; Huang, L. Redevelopment Authority of the City of Philadelphia Land Use and Policy Study; Penn Institute for Urban Research, Econsult Corporation: Philadelphia, PA, USA, 2010.

35. Rosenthal, J.K.; Crauderueff, R.; Carter, M. Urban Heat Island Mitigation Can Improve New York City's Environment; Sustainable South Bronx: New York, NY, USA, 2008.

36. Schilling, J.M.; Mallach, A. Cities in Transition: A Guide for Practicing Planners; American Planning Association: Washington, DC, USA, 2012.

37. Carmona, M.; de Magalhaes, C. Public space management: Present and potential. J. Environ. Plan. Manag. 2006, 49, 75-99. [CrossRef]

38. Holland, C.; Clark, A.; Katz, J.; Peace, S. Social Interactions in Urban Public Places; Policy Press: Bristo, UK, 2007.

39. Worpole, K.; Knox, K. The Social Value of Public Spaces; Joseph Rowntree Foundation: York, UK, 2008. 
40. Greenman, J. Caring Spaces, Learning Places: Children's Environments that Work; Exchange Press: Redmond, WA, USA, 1988.

41. Thompson, C.W. Urban open space in the 21st century. Landsc. Urban Plan. 2002, 60, 59-72. [CrossRef]

42. Tylecote, M. The wildscapes case studies. In Urban Wildscapes; Jorgensen, A., Keenan, R., Eds.; University of Sheffield: Sheffield, UK, 2008; pp. 93-104.

43. Taylor, D. Public Space Lessons: Land in Limbo: Making the Best Use of Vacant Urban Spaces; Commission for Architecture and the Built Environment: London, UK, 2008.

44. Franck, K.A.; Stevens, Q. Loose Space: Possibility and Diversity in Urban Life; Routledge: London, UK, 2007.

45. Schukoske, J.E. Community development through gardening: State and local policies transforming urban open space. N. Y. Univ. J. Legis. Public Policy 1999, 3, 351-392. [CrossRef]

46. City of Philadelphia Redevelopment Authority. City of Philadelphia Redevelopment Authority. 2009. Available online: http://www.phila.gov/pra/buyingProperty.html (accessed on 5 April 2016).

47. Atlanta Regional Commission. Senior Community Garden Initiative. 2014. Available online: http://www.atlantaregional.com/aging-resources/health-wellness/community-garden-initiative (accessed on 5 May 2016).

48. City of Chicago. Greencorps Chicago. 2014. Available online: http://www.cityofchicago.org/city/en/ depts/cdot/provdrs/conservation_outreachgreenprograms/svcs/greencorps_chicago.html (accessed on 25 August 2015).

49. NYC Parks GreenThumb. About: NYC Parks GreenThumb. 2014. Available online: http://www. greenthumbnyc.org/about.html (accessed on 6 September 2015).

50. Bonham, J.B., Jr.; Spilka, G. Urban Vacant Land: Issues and Recommendations; Pennsylvania Horticultural Society: Philadelphia, PA, USA, 1995.

51. Gowda, V. Whose garden is it. Governing 2002, 5, 40-41.

52. Goldstein, J.; Jensen, M.; Reiskin, E. Urban Vacant Land Redevelopment: Challenges and Progress; Lincoln Institute of Land Policy: Cambridge, MA, USA, 2001.

53. Econsult Corporation, Penn Institute for Urban Research, \& May 8 Consulting. Vacant Land Management in Philadelphia: The Costs of the Current System and the Benefits of Reform. 2010. Available online: http://planphilly.com/uploads/media_items/http-planphilly-com-sites-planphilly-com-fileseconsult_vacant_land_full_report-pdf.original.pdf (accessed on 14 May 2016).

54. Philadelphia Water Department. Amended Green City Clean Waters: The City of Philadelphia's Program for Combined Sewer Overflow Control Program Summary. 2011. Available online: http://www. phillywatersheds.org/doc/GCCW_AmendedJune2011_LOWRES-web.pdf (accessed on 5 September 2015).

55. Neukrug, H.M. Clean Water, Green City: Blending Interests of Land and Water; Office of Watersheds: Philadelphia, PA, USA, 2009.

56. The Pennsylvania General Assembly. The Pennsylvania General Assembly. 2012. Available online: http:/ / www.legis.state.pa.us/index.cfm (accessed on 19 June 2015).

57. PennPraxis. Green2015: An Action Plan for the First 500 Acres. 2010. Available online: https://www.design. upenn.edu/pennpraxis/work/green-2015-action-plan-500-new-acres (accessed on 14 May 2016).

58. Branas, C.C.; Cheney, R.A.; MacDonald, J.M.; Tam, V.W.; Jackson, T.D.; Ten Have, T.R. A differencein-differences analysis of health, safety, and greening vacant urban space. Am. J. Epidemiol. 2011, 174, 1296-1306. [CrossRef] [PubMed]

59. Gillen, K. Testimony to the Philadelphia City Council; The Nature Conservancy: Philadelphia, PA, USA, 2012. Available online: https://www.nrdc.org/sites/default/files/wat_13022701a.pdf (accessed on 14 May 2016).

60. Blakeman, C.; Brown, B.; Fitzpatrick, B.T.; Shaw, I.; Williamson, A. City-Wide Brownfield Redevelopment Plan; Report Prepared for the City of Roanoke, VA, USA; City Council: Roanoke, VA, USA, 2008.

61. Shah, A. Why Is Biodiversity Important? Who Cares? Available online: http://www.globalissues.org/ article/170/why-is-biodiversity-important-who-cares (accessed on 12 September 2015).

62. Accordino, J.; Johnson, G.T. Addressing the vacant and abandoned property problem. J. Urban Aff. 2000, 22, 301-315. [CrossRef]

(C) 2016 by the author; licensee MDPI, Basel, Switzerland. This article is an open access article distributed under the terms and conditions of the Creative Commons Attribution (CC-BY) license (http://creativecommons.org/licenses/by/4.0/). 